\title{
Predictors of in-stent restenosis in patients undergoing percutaneous coronary intervention
}

\section{Perkütan koroner girişim geçiren hastalarda stent-içi restenozun öngörücüleri}

\author{
İsmail Polat Canbolat ${ }^{1}\left(\mathbb{D}\right.$, Alev Arat-Özkan ${ }^{2}$ \\ ${ }^{1}$ Department of Cardiology, Demiroglu Bilim University Faculty of Medicine, Istanbul, Turkey \\ ${ }^{2}$ Department of Cardiology, Istanbul University Cerrahpaşa Faculty of Medicine, Istanbul, Turkey
}

\begin{abstract}
Objectives: Clinical, angiographic, and biochemical factors associated with in-stent restenosis were retrospectively analyzed in patients undergoing percutaneous coronary intervention.

Materials and methods: Patients who had undergone follow-up angiography for de novo lesions six months after bare metal stent (BMS) and nine months after drug eluting stent (DES) implantation were retrospectively analyzed. Demographic, angiographic, and clinical parameters were collected from our patient database: In-stent restenosis (ISR) was defined as $>50 \%$ narrowing of stent lumen or coronary artery $5 \mathrm{~mm}$ adjacent to stent edges. Retrospectively 319 patients with a mean age of 57.6 years were included in this study.

Results: In-stent restenosis occurred in $26.6 \%$ of the patients with drug-eluting stent and $36.5 \%$ of the patients with bare-metal stent implanted. Tobacco use was significantly more frequent among patients with in-stent restenosis.

Conclusion: In-stent restenosis rates in our study is consistent with the literature. Studies are ongoing to overcome this challenging problem.
\end{abstract}

Keywords: Bare-metal stent, drug-eluting stent, in-stent restenosis

$\ddot{o z z}$

Amaç: Perkütan koroner girişim geçiren hastalarda stent-içi restenoz ile ilişkili klinik, anjiyografik ve biyokimyasal faktörler retrospektif olarak analiz edildi.

Gereç ve yöntemler: Çıplak metal stent (ÇMS) uygulamasından altı ay sonra ve ilaç kaplı stent (IKS) implantasyonundan dokuz ay sonra de novo lezyonları için kontrol anjiyografi çekilen hastalar retrospektif olarak analiz edildi. Hasta veritabanından demografik, anjiyografik ve klinik parametreler toplandı: stent-içi restenoz (SiR) stent kenarlarına $5 \mathrm{~mm}$ komşu stent lümeni veya koroner arterinin $>\% 50$ daralması olarak tanımlandı. Yaş ortalaması 57.6 olan 319 hasta retrospektif olarak çalışmaya dahil edildi.

Bulgular: Stent içi restenoz IKS hastalarının \%26.6'sında ve ÇMS implantasyonu olan hastalarının \%36.5'inde gerçekleşti. Stent içi restenoz olan hastalarda tütün kullanımı anlamlı olarak daha fazla idi.

Sonuç: Çalışmamızda stent içi restenoz oranları literatür ile uyumludur. Bu zorlayıcı sorunu çözmek için çalışmalar devam etmektedir. Anahtar sözcükler: Çıplak metal stent, ilaç kaplı stent, stent içi restenoz.

Atherosclerosis is the leading cause of death despite improvements in the outcomes of cardiovascular diseases (CVD). ${ }^{[1,2]}$ More patients are surviving their first CVD event and are at high risk of recurrence. Chronic inflammation is the major factor for the development and progression of atherosclerosis. ${ }^{[3,4]}$ Atherosclerotic cardiovascular disease is the most common form of coronary artery disease, leading to narrowing of coronary arteries. 
Percutaneous coronary intervention (PCI) is the most commonly preferred approach in most patients. ${ }^{[5]}$ In-stent restenosis (ISR), defined as $>50 \%$ narrowing of stent lumen or coronary artery $5 \mathrm{~mm}$ adjacent to stent edges, is a restricting complication of $\mathrm{PCI}$ leading to repeat revascularization. Inflammation, patient characteristics, and mechanical factors have been characterized as predictors of ISR. ${ }^{[6-9]}$

In this study, we retrospectively analyzed the effect of clinical, angiographic, and biochemical factors on ISR in patients who underwent PCI.

\section{MATERIALS AND METHODS}

Patients who had undergone control angiogram six months after bare metal stent (BMS) and nine months after drug eluting stent (DES) implantation for de-novo lesions at Istanbul University Cardiology Institute between October 2007-April 2008 and January 2011April 2012 were retrospectively analyzed. Patients without control angiogram $(n=181)$, patients with only coronary balloon angioplasty $(n=46)$, and stent implantation to bypass graft veins $(n=20)$ were excluded from the study. Demographic, angiographic, and clinical parameters were collected from our patient database: Gender, age, primary indication for $\mathrm{PCI}$, creatinine, diabetes mellitus (DM), history of coronary artery disease (CAD), history of heart failure, history of cerebrovascular disease, dyslipidemia, tobacco use, and hypertension. In-stent restenosis (ISR) was defined as $>50 \%$ narrowing of stent lumen or coronary artery $5 \mathrm{~mm}$ adjacent to stent edges.

The study was conducted with the approval of the Local Research Ethics Committee. A written informed consent was obtained from each patient. The study was conducted in accordance with the principles of the Declaration of Helsinki.

\section{Statistical analysis}

Continuous variables were expressed as mean \pm standard deviation and categorical variables

Table 1. Baseline demographic and clinical characteristics

\begin{tabular}{lccc}
\hline & $\mathrm{n}$ & $\%$ & Mean \pm SD \\
\hline Age (year) & & & $57.7 \pm 10.1$ \\
Gender & 68 & 21.3 & \\
$\quad$ Female & 178 & 55.8 & \\
Hypertension & 216 & 67.7 & \\
Dyslipidemia & 92 & 28.8 & \\
Diabetes mellitus & 139 & 43.6 & \\
History of CAD & 91 & 28.5 & \\
Family history of CAD & 170 & 53.3 & \\
Tobacco use & 216 & 67.7 & \\
Indication for intervention (stable AP) & 99 & 31 & \\
In-stent restenosis & & & \\
\hline
\end{tabular}

Mean \pm SD: Mean \pm standard deviation; CAD: Coronary artery disease; AP: Angina pectoris.

Table 2. Baseline angiographical and stent characteristics

\begin{tabular}{lccc}
\hline & $\mathrm{n}$ & $\%$ & Mean $\pm \mathrm{SD}$ \\
\hline Stent diameter $(\mathrm{mm})$ & & & $2.9 \pm 0.4$ \\
Stent length $(\mathrm{mm})$ & & & $20.0 \pm 6.0$ \\
Drug-eluting stent usage & 83 & 26.6 & \\
Left anterior descending artery and & 132 & 41.6 & \\
side-branches & & & \\
Circumflex artery and side branches & 77 & 24.3 & \\
Right coronary artery and side branches & 107 & 33.8 & \\
\hline
\end{tabular}


Table 3. Demographic and clinical characteristics of patients with and without in-stent restenosis

\begin{tabular}{|c|c|c|c|c|c|c|c|}
\hline & \multicolumn{3}{|c|}{ ISR $(+)(n=99)$} & \multicolumn{3}{|c|}{ ISR (-) $(n=220)$} & \multirow[b]{2}{*}{$p$} \\
\hline & $\mathrm{n}$ & $\%$ & Mean \pm SD & $\mathrm{n}$ & $\%$ & Mean $\pm S D$ & \\
\hline Age (year) & & & $58.3 \pm 10.8$ & & & $57.4 \pm 9.8$ & 0.494 \\
\hline $\begin{array}{l}\text { Gender } \\
\text { Female }\end{array}$ & 16 & 16.2 & & 52 & 23.6 & & 0.132 \\
\hline Dyslipidemia & 55 & 55.6 & & 161 & 73.2 & & 0.002 \\
\hline Diabetes mellitus & 29 & 29.3 & & 63 & 28.6 & & 0.905 \\
\hline Hypertension & 50 & 50.5 & & 128 & 58.2 & & 0.202 \\
\hline Tobacco use & 62 & 62.6 & & 108 & 49.3 & & 0.028 \\
\hline
\end{tabular}

ISR: In-stent restenosis; SD: Standard deviation.

Table 4. Angiographical and stent characteristics in patients with and without in-stent restenosis

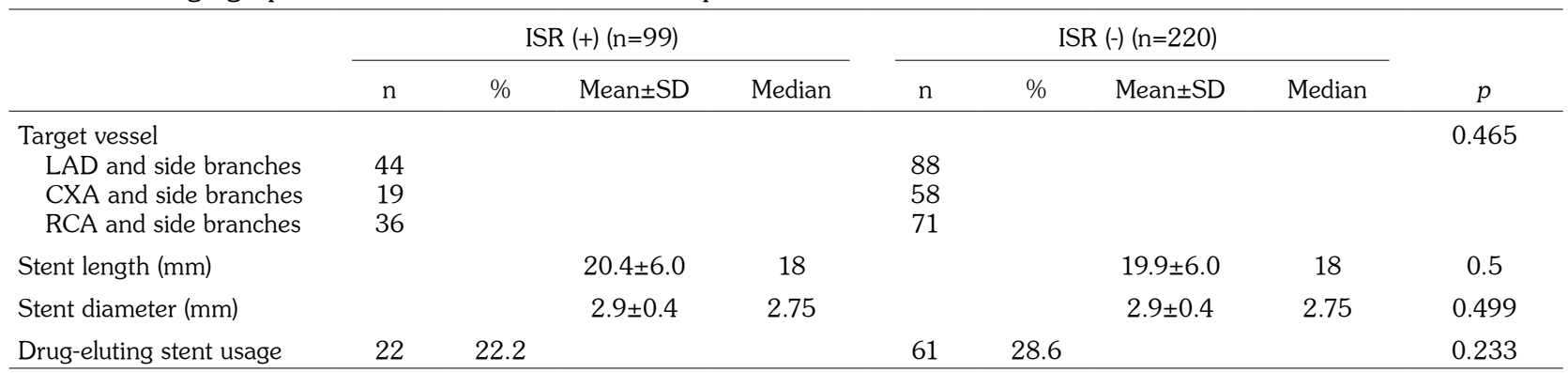

ISR: In-stent restenosis; SD: Standard deviation; LAD: Left anterior descending artery; CXA: Circumflex artery; RCA: Right coronary artery.

were expressed as percentage (\%). Categorical variables were compared using the chi-square test. Student's t-test was used to compare the continuous variables. All analyses were performed using SPSS for Windows version 15.0 software (SPSS, Inc., Chicago, Illinois, USA). A two-sided value less than 0.05 was considered statistically significant within a 95\% confidence interval (CI).

\section{RESULTS}

A total of 319 patients with a mean age of 57.6 years were included in this retrospective study. Demographic and clinical characteristics are presented in Table 1 . The angiographic characteristics of our patient population is demonstrated in Table 2. In-stent restenosis occurred in 99 patients (31\%) of the entire group. Patients were divided into two groups according to ISR. Table 3 compares the clinical characteristics of patients with and without ISR. Table 4 compares the angiographic characteristics of patients with and without ISR. Tobacco usage was significantly more frequent among patients with ISR. Dyslipidemia was significantly more common in patients without ISR. There was no difference in angiographic and stent characteristics between the groups.

\section{DISCUSSION}

In this study, factors associated with ISR were investigated in our population. In our study, ISR prevalence was 31\%. In-stent restenosis occurred in $26.6 \%$ of the patients with DES and $36.5 \%$ with BMS. Although there is limited data on the prevalence of ISR in our country, ISR occurred in $27.9 \%$ of patients who underwent BMS implantation in our clinic between 1995 and 1996. ${ }^{[10]}$ Drug-eluting stents were developed to lower the frequency of ISR. In our study population, although patients with DES implantation had lower rate of ISR, this difference did not attain significance. High rate of ISR in the DES group may be attributed to smaller stent diameter, longer stents, and complex coronary interventions.

Previous studies have reported female gender is associated with higher rates of ISR,${ }^{[1]}$ however, 
in our study, there was no significant difference between genders according to ISR.

Use of tobacco leads to endothelial disfunction, inflammation, and aggravation of cardiovascular disease. ${ }^{[12,13]}$ Turak et al. ${ }^{[14]}$ investigated the role of neutrophil/lymphocyte ratio in predicting BMS restenosis and reported smoking was an associated factor of ISR. In our study, tobacco use was significantly more common in patients with ISR although we did not have any data on continuous tobacco use until follow-up angiography.

Patients with dyslipidemia in our study group had significantly lower rates of ISR. This finding seemed conflicting as statins have a protective effect on neointimal hyperplasia and this finding may be attributed to statin use among patients with dyslipidemia. ${ }^{[15]}$

We investigated the target vessel as a potential factor for ISR. Stent implantation of the left anterior descending artery showed predisposition towards ISR. ${ }^{[16]}$

In conclusion, the ISR rates determined in our study was consistent with the literature. Studies are ongoing to overcome this challenging problem.

\section{Declaration of conflicting interests}

The authors declared no conflicts of interest with respect to the authorship and/or publication of this article.

\section{Funding}

The authors received no financial support for the research and/or authorship of this article.

\section{REFERENCES}

1. Townsend N, Nichols M, Scarborough P, Rayner M. Cardiovascular disease in Europe--epidemiological update 2015. Eur Heart J 2015;36:2696-705.

2. Weir HK, Anderson RN, Coleman King SM, Soman A, Thompson TD, Hong Y, et al. Heart Disease and Cancer Deaths - Trends and Projections in the United States, 1969-2020. Prev Chronic Dis 2016;13:E157.

3. Mallika V, Goswami B, Rajappa M. Atherosclerosis pathophysiology and the role of novel risk factors: a clinicobiochemical perspective. Angiology 2007;58:513-22.

4. Libby P. Inflammation in atherosclerosis. Nature 2002;420:868-74.

5. Neumann FJ, Sousa-Uva M, Ahlsson A, Alfonso F, Banning AP, Benedetto U, et al. 2018 ESC/EACTS Guidelines on myocardial revascularization. Eur Heart J 2019;40:87-165.

6. Rajagopal V, Rockson SG. Coronary restenosis: a review of mechanisms and management. Am J Med 2003;115:547-53.

7. Bennett MR. In-stent stenosis: pathology and implications for the development of drug eluting stents. Heart 2003;89:218-24.

8. El-Omar MM, Dangas G, Iakovou I, Mehran R. Update on In-stent Restenosis. Curr Interv Cardiol Rep 2001;3:296-305.

9. Cutlip DE, Chauhan MS, Baim DS, Ho KK, Popma JJ, Carrozza JP, et al. Clinical restenosis after coronary stenting: perspectives from multicenter clinical trials. J Am Coll Cardiol 2002;40:2082-9.

10. Gurmen T, Babalik E, Gulbaran M, Öztürk S, Öztürk M. Intracoronary stent implantation: six months results, predictors of stent restenosis. Arch Turk Soc Cardiol 1998;26:408-15.

11. Goldberg SL, Loussararian A, De Gregorio J, Di Mario C, Albiero R, Colombo A. Predictors of diffuse and aggressive intra-stent restenosis. J Am Coll Cardiol 2001;37:1019-25.

12. Bermudez EA, Rifai N, Buring JE, Manson JE, Ridker PM. Relation between markers of systemic vascular inflammation and smoking in women. Am J Cardiol 2002;89:1117-9.

13. Taylor BV, Oudit GY, Kalman PG, Liu P. Clinical and pathophysiological effects of active and passive smoking on the cardiovascular system. Can J Cardiol 1998;14:1129-39.

14. Turak O, Ozcan F, Isleyen A, Tok D, Sokmen E, Buyukkaya $\mathrm{E}$, et al. Usefulness of the neutrophil-tolymphocyte ratio to predict bare-metal stent restenosis. Am J Cardiol 2012;110:1405-10.

15. Walter DH, Schächinger V, Elsner M, Mach S, AuchSchwelk W, Zeiher AM. Effect of statin therapy on restenosis after coronary stent implantation. Am J Cardiol 2000;85:962-8.

16. Kastrati A, Schömig A, Elezi S, Schühlen $H$, Dirschinger J, Hadamitzky M, et al. Predictive factors of restenosis after coronary stent placement. J Am Coll Cardiol 1997;30:1428-36. 